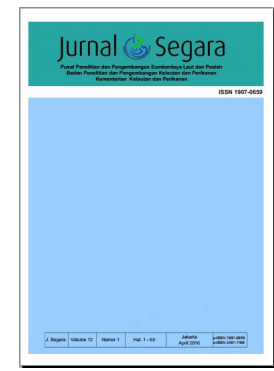

JURNAL SEGARA

http://ejournal-balitbang.kkp.go.id/index.php/segara

ISSN : 1907-0659

e-ISSN : 2461-1166

Acreditation Number : 158/E/KPT/2021

\title{
A NEW OCEANOGRAPHIC DATA PORTAL: PADJADJARAN OCEANOGRAPHIC DATA CENTRE (PODC)
}

\author{
Ibnu Faizal'1), Noir P. Purba1), Darryl A. Valino2), Madihah J. Sidik', Amarif Abimanyu'), \\ Tonny Bratasena ${ }^{5}$, Fajri Ramdhani6), \& Ajeng Wulandari ${ }^{7)}$ \\ ${ }^{1)}$ Marine Research Laboratory (MEAL), Universitas Padjadjaran \\ ${ }^{2}$ Marine Science Institute, University of The Philippines \\ ${ }^{3}$ BBorneo Marine Research Institute, Universiti Malaysia Sabah \\ 4)Yayasan Segara Bakti Khatulistiwa, \\ 5)KOMITMEN Research Group, Universitas Padjadjaran \\ 6)Alumni of Marine Science, Universitas Padjadjaran \\ ${ }^{7)}$ Marine Conservation Magister Program, Universitas Padjadjaran
}

Received: 24 August 2021; Revised: 25 ovember 2021; Accepted: 22 Desember 2021

\begin{abstract}
Understanding the physio-chemical oceanic and atmospheric processes is critical in monitoring climate change. Archipelagic and Small Island countries are vulnerable to the detrimental effects of climate change, and open access oceanic databases can solve data limitations leading to further development of action plans and government policies. A website was developed (www.isea-podc.org) to distribute and augment free oceanographic data based on various in-situ sampling instruments. Oceanographers review the data collected and stored in the portal. It is led by the Marine Research Laboratory (MEAL), Padjadjaran University, in partnership with Marine Science Institute (MSI), University of the Philippines. This framework supplements information that can support marine ecosystems, fisheries, and climate science studies. Furthermore, all data are accessible to not only the academe but also decision-makers in all aspects. The data sources are student research and the new instruments (RHEA and ARHEA) developed by MEAL. In the future, the portal will be integrated with other government institutional data to provide other functional features and can yield network-wide analyses. In the next phase, collaboration from ASEAN countries should be conducted to gain more impact and provide robust datasets.
\end{abstract}

Keywords : Ocean Data, Indonesia Seas, Oceanographic Condition, RHEA-ARHE. 


\section{INTRODUCTION}

Although the ocean has an essential role in human life, most of the crucial basic information about our oceans is currently only available to a small community of researchers and experts in related fields (Buck er al., 2019) or for a limited time (Durand er al., 2010). Resources, data, and science are essential in achieving the 17 SDGs, following the Three UN's sustainability pillars: environment, society, and economy (Abram er al., 2019; Abram er al., 2019). SDG targets require a solid scientific basis/foundation, and this can be provided by the Earth Observation (EO) system (Bensana er al., 1999) and numerical models (Lubchenco er al., 2015). Several guidance frameworks for crucial variables in the marine and climate sector, such as Essential Climate Variables (ECVs), Essential Ocean Variables (EOVs) (Miloslavich er al., 2018), and Global Climate Indicators, have been created to meet the monitoring needs of both the community and stakeholders. However, linking scientific knowledge and marine data to the pillars of sustainable development remains a challenge (von Schuckmann er al., 2020). In addition, improving the quality of marine science is very dependent on the disclosure of relevant marine data, especially in situ data that can be used as a primary monitoring tool.

One of the most fundamental challenges in studying and monitoring ocean parameters, such as biogeochemistry, is the very high spatial (resolution can vary from a few meters to hundreds of kilometres) and temporal variability (seconds to decades). The ocean's vastness is a challenge where it is financially costly to deploy an instrument that can simultaneously cover the appropriate location and time (Wang er al. 2019). One solution that can be done to deal with the problem of spatial and temporal coverage is remote sensing. Remote sensing in the marine science world itself has been used to obtain essential parameters, such as Sea Surface Temperature (SST) (Carr er al., 2021). In addition to SST, the use of satellites is commonly used to obtain total suspended solids (TSS) (Caballero er al., 2018) and Sea Level (Vignudelli er al., 2019). Although it can be used to solve data at the sea surface, satellite remote sensing is less effective for analysing and monitoring the ocean at multi-layered depths (Dubovik er al., 2021). Until now, researchers still rely on field observations and also modelling for multi-layer water mass analysis. One example of an openly accessible multi-layer operational global model is the Hybrid Coordinate Ocean Model (HYCOM) (Chassignet er al., 2007).

Currently, several data portals provide many marine parameters openly and with varying coverage, ranging from regional to global, such as ERDDAP owned by NOAA, Copernicus Marine Service, INCOIS from India (Pattabhi Rama Rao er al., 2018) and APDRC. ERDDAP is a data server owned by NOAA and offers gridded and tabular scientific data in various formats commonly used in marine research. ERDDAP itself also offers several data sources such as buoys and satellite-derived. ERDDAP has many data sources because ERDDAP acts as an intermediary between the user and some remote data servers, such as NASA's Ocean Color and AVISO. In addition to ERDDAP, Copernicus Marine Environment Monitoring Service (CMEMS) also provides various data on marine parameters such as Physical and Biogeochemistry on a regional and global scale. For global coverage data, most of the data available on the CMEMS website are modelled data with many levels of depth. The data available on the CMEMS server can be accessed openly by registering in advance, where the registration process is free. In Indonesia, global model data provided by several overseas servers has become a common practice. So far, using a global scale model for Indonesian regional waters still has several shortcomings, such as coarse spatial resolution and the input model used where there may be some regional factors that are ignored. This shortcoming can be seen especially in coastal areas where complex coastal dynamics sometimes cannot be represented by global-scale models. Moreover, as a substitute, many researchers or experts make their regional model designs using the modelling software of their choice and input data from field observations that are more accurate.

The existence of a portal database, for marine data, especially in Indonesia, is still minimal where the existence of the database is still in each agency/ operator of data collection (Setyowati er al., 2018). The One Map, One Policy (Shahab, 2016) which started in 2010, also seems to accommodate more terrestrial data needs. To deal with the problems mentioned in the previous paragraphs, we are trying to create an open Indonesian marine data portal platform with the name Padjadjaran Ocean Data Center (PODC) (https://iseapodc.org/). The PODC itself was initially created only to contain marine data obtained from expeditions and the instrument that has been developed, namely RHEA (Purba er al., 2017).

In Indonesia, PODC is the first marine data portal website with various kinds of marine data from various agencies and researchers with an open-access nature. This will support the one map policy that provides complete information to users under Presidential Regulation 9 of 2016. Currently, PODC is being developed to become a marine data portal platform for the whole world. It contains various marine data from various agencies and individual researchers, especially in archipelagic countries. PODC itself is open-access, where anyone worldwide can access the data available 
on the PODC server. Conversely, researchers or interested agencies can load the data to be displayed on the PODC website.

\section{METHODOLOGY}

\section{Framework}

PODC is a data portal that can store large amounts of data (big data). This portal is expected to be one of the references in data analysis in the marine sector. In particular, this portal provides data for free to its users. The data system received by the data portal can be in raw data and data analysis. The data in this portal come from anywhere with the standards that have been set for uploading.

On the infrastructure of the website, several programs and tools were used to support it. Generally, it is divided into three parts, namely Front End, Back End, and Database. Front End using HTML, CSS (Duckett, 2011), and JavaScript (Crockford, 2008) versions 5,3, and 8, respectively. Hypertext Preprocessor (PHP) version 7.4.16 (Tatroe \& Maclntyre, 2020) was used to support Back End and lastly for database, Structured Query Language (SQL) (Stonebraker, 2010) was used to back up.

\section{Workflow}

The creation of this data portal is carried out in several staqes, 1) Concept and framework development.
2) Data collection, 3) Website design development, and 4) Data Usage Simulation. The data collection referred to in this case includes literature reviews such as browsing data portals around the world. Then the other data is the collection of field data from various sources, which will later be entered into the data portal. Next, website design is done by creating wireframes.

Website development generally includes changes to the User Interface (UI) and User Experience (UE). The PODC website is divided into two types of displays, namely static pages and interactive pages. The content of the website can be seen in Figure 1.

The management of the PODC Website is carried out by involving the IT team and management personnel in which there is a work structure. Currently, the server for the data is tested independently, and it is hoped that later it can be stored at Padjadjaran University's servers and other partners. Furthermore, in the data validation process, PODC invites experts from within and outside the country. This team of experts is tasked with screening the data, which in the final state, the data is ready to be published to the general public. However, this portal also publishes data in raw data where the data analysis is left to the user.

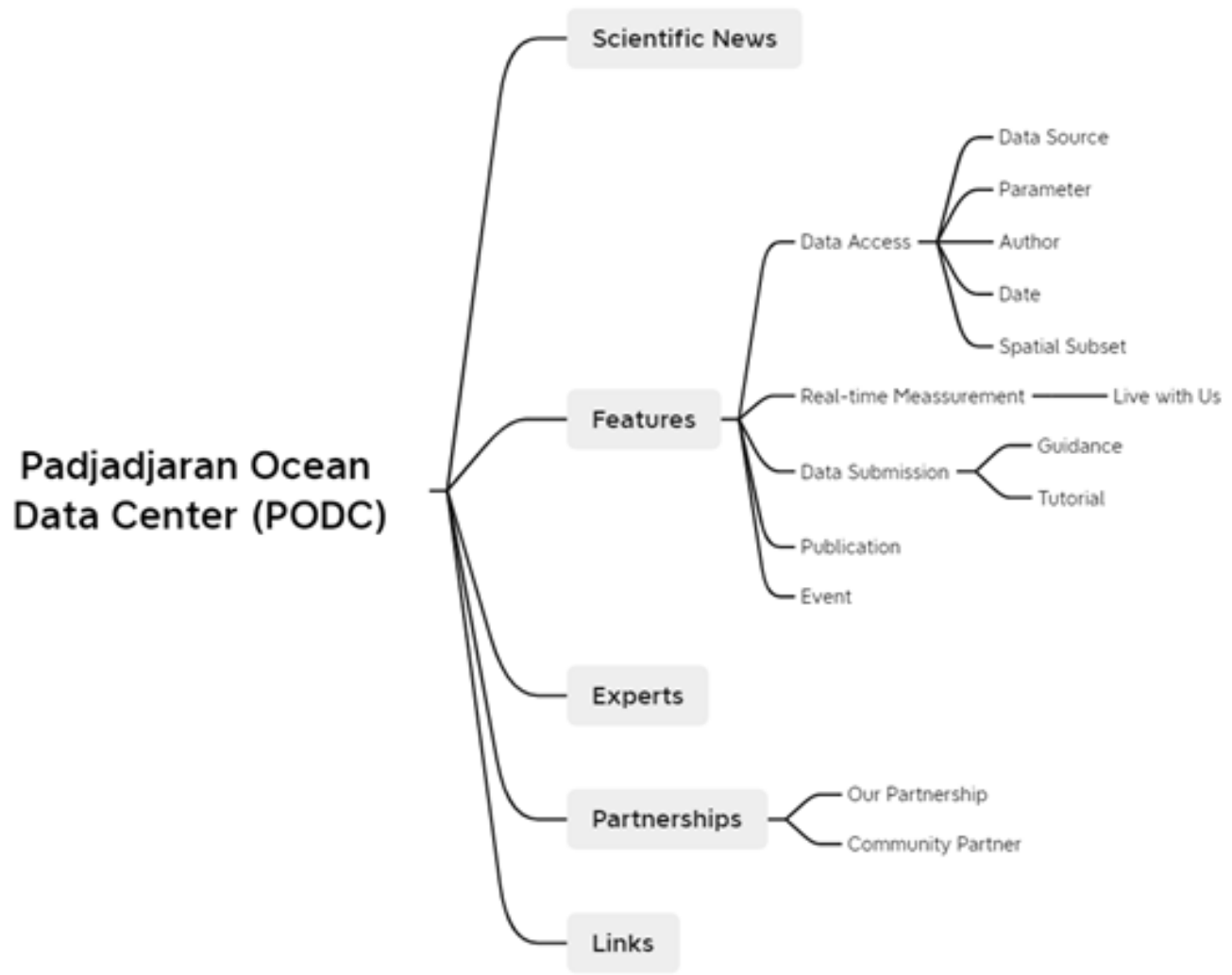

Figure 1. Mind map for the PODC Website. There are Two Interactive Pages consists of Data Acess and Data Submission. Source: Personal Documentation 


\section{RESULTS AND DISCUSSION}

\section{Data characteristics}

There are many data portals in the world providing valuable data about the marine environment. One thing unique with the PODC is that it provides a wide range of heterogeneous data spanning from in situ, model output, and live reports (Table 1).

The data in the PODC data portal server are mainly obtained from individual researchers from Indonesia and the Philippines. This data is stored in the PODC server using the tabular Comma Separated Values (.csv) format. In the PODC CSV format, there is information about the coordinates of the data location in the Decimal Degree format. Therefore, some data with different coordinate formats must go through a coordinate system transformation first. In addition to the coordinate format, the data that enters the PODC server will also undergo a unit format screening (unit of speed, salinity, etc.) first by the expert team so that the data accessed by the user has a uniform format.

The data stored in the PODC server is classified based on several categories, namely data sources, observation parameters, and data timescales. The data sources can vary from several activities/ instruments such as ARHEA, expedition/research (field observation), observation instruments (e.g. drifters, buoys, etc.), or data from modelling outputs. For parameter class division, currently, the data stored in the PODC server will be divided into the following categories: Atmospheric, Physics, Chemistry, Biology, Biota and Fishery, and Ecosystem. In addition to presenting data from field measurements or direct surveys, the PODC was also planned to provide more than 15 other data sources by attracting services from related websites. The choice of other data sources is dominated by accessible data access so that there are no issues related to licenses or permits.

\section{Data Processes}

This data portal was intended to accommodate internal data results from both national and international contributors. A form has been provided on the website page for how potential partners can support the data. Data that enter the PODC server will receive two different processing (figure. 2). The first processing is where the raw data is directly displayed on the website. This is done to support the real-time visualization and monitoring available on the PODC. For the second processing, where raw data from contributors will go through a screening process first by a regional expert team. Screening or inspection is carried out to ensure that the data that the user will access are ready to use and ensures convenience from the user's side.

The advantage of this data portal website is the live expedition where surveys can be directly monitored on the website. Users from scientific and non-scientific communities can download data directly with only email registration, so it does not take long to access it.

\section{User Interface (UI) and User Experience (UX)}

PODC website also provides a visualization of data locations stored on the server (Figure. 3a). This creates an ease of use for users to see whether the data offered will suit the users' needs. The UI of PODC itself is currently still being maximized for computer users, the reason being that the main target of PODC itself is projected to be mainly computer users who will process the data. From the results of the feedback received from the users, several inputs were obtained for a better display, such as adding data features for the ecosystem and atmosphere.

This data portal also provides articles related to marine-related issues (Scientific News). The main features in a data portal website are, of course, Data Access and Data Submission. In this case, the Data Access menu on the PODC website has a simple interface to create a user-friendly environment for users experienced in marine data and those who are

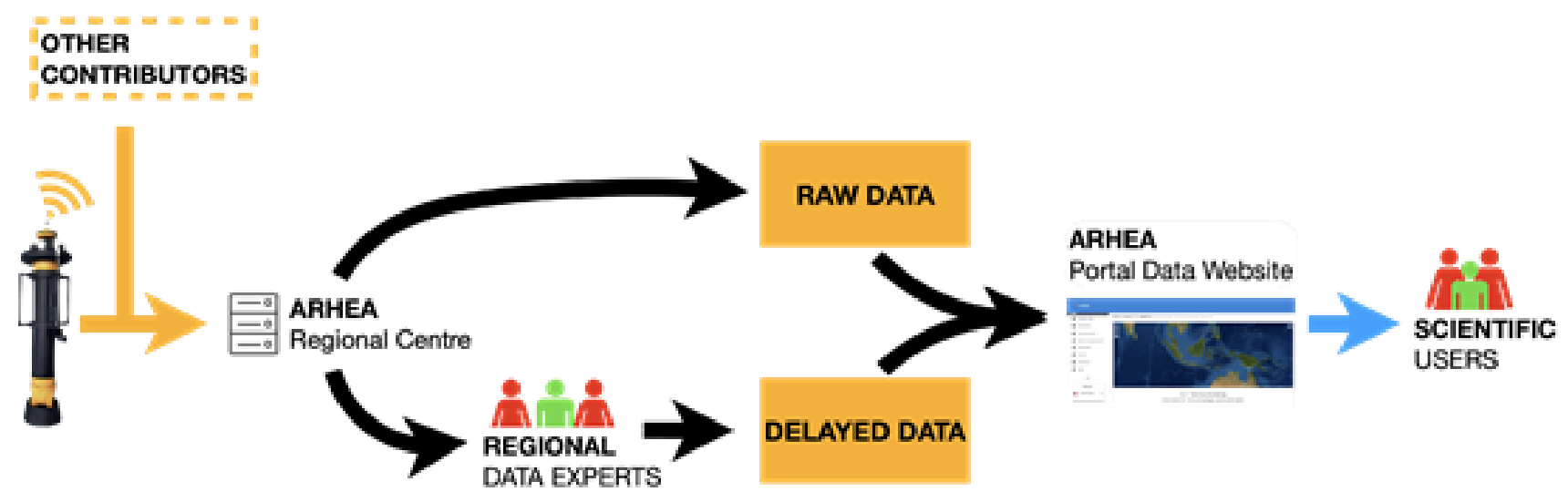

Figure 2. Data Processing system. Source: Personal Documentation 
Table 1.

List of Data Sources drawn by Services by PODC Website

\begin{tabular}{|c|c|c|c|c|}
\hline No & Portal Data & Website & Accessibility & Remarks \\
\hline 1 & $\begin{array}{l}\text { BODC (British Oceanographic } \\
\text { Data Centre) }\end{array}$ & $\begin{array}{l}\text { https://www.bodc. } \\
\text { ac.uk/ }\end{array}$ & $\begin{array}{l}\text { Free with email } \\
\text { registration }\end{array}$ & \\
\hline 2 & $\begin{array}{l}\text { NODC (National Oceanographic } \\
\text { Data Centre) }\end{array}$ & $\begin{array}{l}\text { https://www.nodc. } \\
\text { noaa.gov/ }\end{array}$ & $\begin{array}{l}\text { Free with email } \\
\text { registration }\end{array}$ & $\begin{array}{l}\text { global, } \\
\text { in-situ data }\end{array}$ \\
\hline 3 & $\begin{array}{l}\text { APDRC (Asia Pacific Data- } \\
\text { Research Center) }\end{array}$ & $\begin{array}{l}\text { http://apdrc. } \\
\text { soest. hawaii. } \\
\text { edu/ }\end{array}$ & Free & $\begin{array}{l}\text { global, combine data } \\
\text { (satellite, in-situ, model, } \\
\text { reanalysis) }\end{array}$ \\
\hline 4 & Marine Copernicus & $\begin{array}{l}\text { https://marine. } \\
\text { copernicus.eu/ }\end{array}$ & $\begin{array}{l}\text { Free with } \\
\text { registration email }\end{array}$ & $\begin{array}{l}\text { global, combine data } \\
\text { (satellite, model, reanalysis) }\end{array}$ \\
\hline 5 & $\begin{array}{l}\text { PODAC (Physical Oceanography } \\
\text { Distributed Active Archive Center) }\end{array}$ & $\begin{array}{l}\text { https://podaac. } \\
\text { jpl.nasa.gov/ }\end{array}$ & $\begin{array}{l}\text { Free with } \\
\text { registration email }\end{array}$ & Global data satellite \\
\hline 6 & $\begin{array}{l}\text { ERDDAP (Environmental Research } \\
\text { Division's Data Access Program) }\end{array}$ & $\begin{array}{l}\text { https://coastwatch } \\
\text { pfeg.noaa.gov/ } \\
\text { erddap/index.htm }\end{array}$ & $\begin{array}{l}\text { Free with } \\
\text { registration email }\end{array}$ & Global data satellite \\
\hline 7 & $\begin{array}{l}\text { GEBCO (General Bathymetric } \\
\text { Chart of the Oceans) }\end{array}$ & $\begin{array}{l}\text { https://www. } \\
\text { gebco.net/ }\end{array}$ & $\begin{array}{l}\text { Free with } \\
\text { registration email }\end{array}$ & Global data satellite \\
\hline 8 & OceanColor & $\begin{array}{l}\text { https://oceancolor } \\
\text { gsfc.nasa.gov/ }\end{array}$ & $\begin{array}{l}\text { r.Free with } \\
\text { registration email }\end{array}$ & Global data satellite \\
\hline 9 & $\begin{array}{l}\text { USGS (United States } \\
\text { Geological Survey) }\end{array}$ & $\begin{array}{l}\text { https://earthex } \\
\text { plorer.usgs.gov/ }\end{array}$ & $\begin{array}{l}\text { Free with } \\
\text { registration email }\end{array}$ & Global data satellite \\
\hline 10 & $\begin{array}{l}\text { Sentinel Data Acces Overview- } \\
\text { The European Space Agency }\end{array}$ & $\begin{array}{l}\text { https://sentinel. } \\
\text { esa.int/web/senti } \\
\text { nel/sentinel-data- } \\
\text { access }\end{array}$ & $\begin{array}{l}\text { Free with } \\
\text { registration email }\end{array}$ & Global data satellite \\
\hline 11 & $\begin{array}{l}\text { AODN (Australian Ocean } \\
\text { Data Network) }\end{array}$ & $\begin{array}{l}\text { https://portal. } \\
\text { aodn. org.au/ }\end{array}$ & $\begin{array}{l}\text { Free with } \\
\text { registration email }\end{array}$ & Global data satellite \\
\hline 12 & Ocean Data Portal & $\begin{array}{l}\text { http://www.ocean } \\
\text { dataportal.org/ }\end{array}$ & $\begin{array}{l}\text { Free with } \\
\text { registration email }\end{array}$ & $\begin{array}{l}\text { Global, combine in-data (satellite, } \\
\text { situ, model, reanalysis) }\end{array}$ \\
\hline 13 & North East Ocean Data & $\begin{array}{l}\text { https://www.north } \\
\text { eastoceandata.or }\end{array}$ & $\begin{array}{l}\text { Free } \\
\mathrm{g} / \mathrm{l}\end{array}$ & Global data satellite \\
\hline 14 & $\begin{array}{l}\text { ECMWF (European Centre for } \\
\text { Medium-Range Weather Forecasts) }\end{array}$ & $\begin{array}{l}\text { https://www. } \\
\text { ecmwf.int/ }\end{array}$ & $\begin{array}{l}\text { Free with } \\
\text { registration email }\end{array}$ & $\begin{array}{l}\text { Global, combine data (satellite, } \\
\text { model, reanalysis) }\end{array}$ \\
\hline 15 & BMKG (Badan Meteorologi dan Geofisika) & $\begin{array}{l}\text { https://dataonline. } \\
\text { bmkg.go.id }\end{array}$ & $\begin{array}{l}\text { Free by Region } \\
\text { Request to } \\
\text { Institution }\end{array}$ & In-situ data \\
\hline 16 & $\begin{array}{l}\text { LAPAN (Lembaga Penerbangan } \\
\text { dan Antariksa Nasional) }\end{array}$ & $\begin{array}{l}\text { https://inderaja- } \\
\text { catalog.lapan. } \\
\text { go.id }\end{array}$ & $\begin{array}{l}\text { Free with } \\
\text { registration email }\end{array}$ & Region Global Data Satellite \\
\hline 17 & $\begin{array}{l}\text { NCEI (National Centers for } \\
\text { Environmental Information) }\end{array}$ & $\begin{array}{l}\text { https://www.ncei. } \\
\text { noaa.gov/ }\end{array}$ & $\begin{array}{l}\text { Free with } \\
\text { registration }\end{array}$ & Global Data Sattelite \\
\hline 18 & $\begin{array}{l}\text { AOOS (Alaska Ocean } \\
\text { Observing System) }\end{array}$ & $\begin{array}{l}\text { https://portal. } \\
\text { aoos.org/ }\end{array}$ & $\begin{array}{l}\text { Free with } \\
\text { registration }\end{array}$ & $\begin{array}{l}\text { Region, combine data (satellite, } \\
\text { in-situ, model, reanalysis) }\end{array}$ \\
\hline 19 & $\begin{array}{l}\text { INCOIS (Indian National Centre } \\
\text { for Ocean Information Services) }\end{array}$ & $\begin{array}{l}\text { https://incois. } \\
\text { gov.in }\end{array}$ & $\begin{array}{l}\text { Free with } \\
\text { registration }\end{array}$ & $\begin{array}{l}\text { Region, combine data (satellite, } \\
\text { in-situ, model, reanalysis) }\end{array}$ \\
\hline 20 & PANGEAE & $\begin{array}{l}\text { https://www. } \\
\text { pangaea.de/ }\end{array}$ & $\begin{array}{l}\text { Free with } \\
\text { registration }\end{array}$ & $\begin{array}{l}\text { Region, combine data (satellite, } \\
\text { in-situ, model, reanalysis) }\end{array}$ \\
\hline 21 & SeaDataNet & $\begin{array}{l}\text { https://www. } \\
\text { seadatanet.org/ }\end{array}$ & $\begin{array}{l}\text { Free with } \\
\text { registration }\end{array}$ & $\begin{array}{l}\text { Region, combine data (satellite, } \\
\text { in-situ, model, reanalysis) }\end{array}$ \\
\hline
\end{tabular}

not (Figure 3c). In accessing PODC data, users can sort the data based on several filters as shown in Figure 3c, such as Data Source, Parameter Data, and Date. In addition, users can also create user-specified $\mathrm{AOI}$ so that the data accessed can follow the user's research area. The complete process of accessing data at PODC will be explained in the next sub-chapter.
The Data Access and Data Submission systems in the PODC data portal were made simple to maximize user convenience in interacting with data on the PODC server. For Data Access, users only need to do a few easy steps. On the Data Access page, the user can choose how wide the user will download the range of data. This can be done by sub setting, either by entering boundary coordinates or drawing the boundary area. 

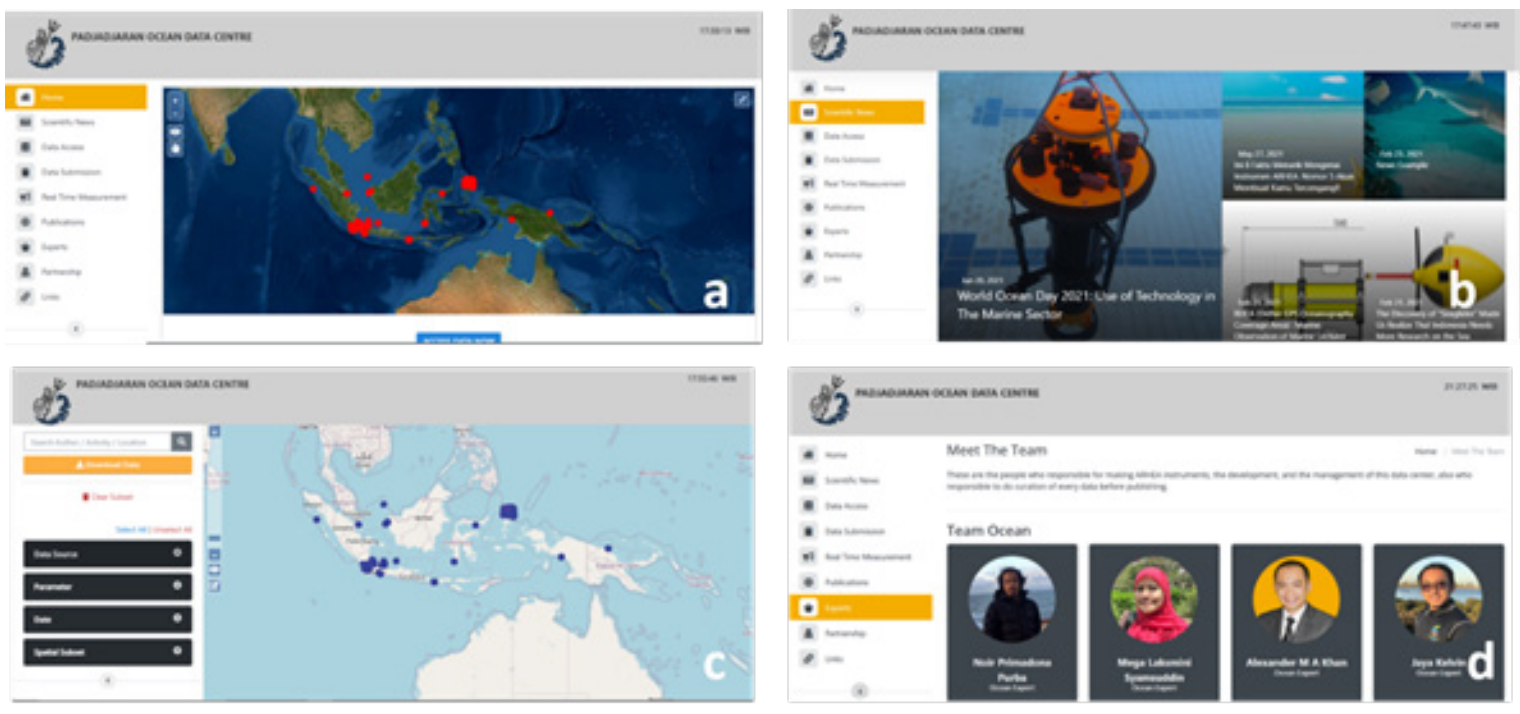

Figure 3. Snapshot of the website (a) front page, b) scientific news, c) map, d) experts. Source: PODC Website (https://isea-podc.org/)

There are several options for selecting/sorting the datasets. Users can choose to download data with specific Data Source options. This Data Source option is composed of the data sources available on the PODC server. Some examples of Data Source choices are an expedition, where data is obtained from direct observation in a research/exploration expedition. Data from academics, both from university activities and student research, can also be selected through this Data Source filter. Apart from the several data sources mentioned, there are also real-time measurement data from the ARHEA instrument. Apart from Data Source filters, users can also choose to filter data based on the desired parameters. As mentioned in section 2.1., that there are many parameter groups contained in the PODC server. In addition to the main groups (atmospheric, physics, chemistry, etc.), specific parameters such as wind speed in the atmospheric group and salinity in the physics group are also specific. All steps designed in the Data Access menu are made to maximize the website's user-friendliness and maximize the suitability of data downloaded by users.

The display of the PODC Data Submission menu can be seen in Figure 4. There is some information that the user must fill in before submitting data in this Menu. The form requires basic information from the data provider, such as name, email, organization, message for admin, and of course, the file that will be submitted to the PODC server. In addition to the information form that the user must fill out, the Data Submission page also contains instructions for users who will submit data in PDF text and video. The PODC provided about 27 parameters that cover the Physical, Biology, and

Figure 4. Types of Data Sets Archived and Served to The End Users.

Source: PODC Website (https://isea-podc.org/) 
Chemistry parameters of the ocean. Users can also add the new parameters that have not been provided by the system yet. This approach was made to make sure all typical data can be accommodated on the website.

The data submission scheme on the PODC website, different processes of how a dataset can be submitted, processed, accepted, and then published. The data received by the server can be directly uploaded to the website www.isea-podc.org in the form of raw data (txt file). This type of raw data has not undergone any screening process. The measurement data are also sent to the experts responsible for screening and following international standards (citation). The data can be downloaded free of charge for scientific purposes (fig. 4). In submitting data, the data owner must first read the instructions contained on the Data Submission page. It contains instructions for the data format used and their units. The data provider can also provide information about the instruments used in obtaining the data to be submitted, such as a water quality checker (WQC) to measure salinity. After the data format is appropriate, the data provider can submit it to the PODC server. Then, the screening is carried out by experts in collaboration with PODC. The expert team in the PODC consists of several experts with different areas of expertise, following the data parameters available in the PODC. The screening process itself is carried out to check several crucial points, such as data quality/validity, outliers in the dataset, format uniformity, etc. After screening, the data will be published on the PODC website and can be directly accessed through the Data Access page. Credits will be given to the data provider and the PODC website when users utilize data from PODC in a study, and instructions for citing PODC data can be found in the Data Access instruction document (insert a link to data access).

In addition, to access and submission of data on PODC website, users can also view real-time measurement data from the instrument ARHEA on the Real-Time Measurement menu (Figure 5). In this menu, users can see the real-time position and observations of the ARHEA instrument. The location of the ARHEA instrument can be seen on the map, represented by red dots on the map. In addition to location, users can also view measurement results from the ARHEA instrument in graphical form. This graph will show the value of the parameters measured by ARHEA (Temperature, Salinity, etc.) based on observation time.

\section{The Future}

The development of the website is an essential concern. Foremost to make sure the website provided ocean data in the region. Several collaborations with institutions and stakeholders in Indonesia and the Philippines must be conducted to support the data. Other things to concern about are access and license of the data. In the process, every single piece of data that is accommodated in the website will have a Digital object identifier (DOI) (Paskin, 2010) to guarantee the data's belonging.

Furthermore, User Interface (UI) development also received from feedback questionnaire (https://bit. ly/FeedbackPODC), which can be used as an initial development to the future. Since the day of the website operation, there have been around 50 feedbacks come

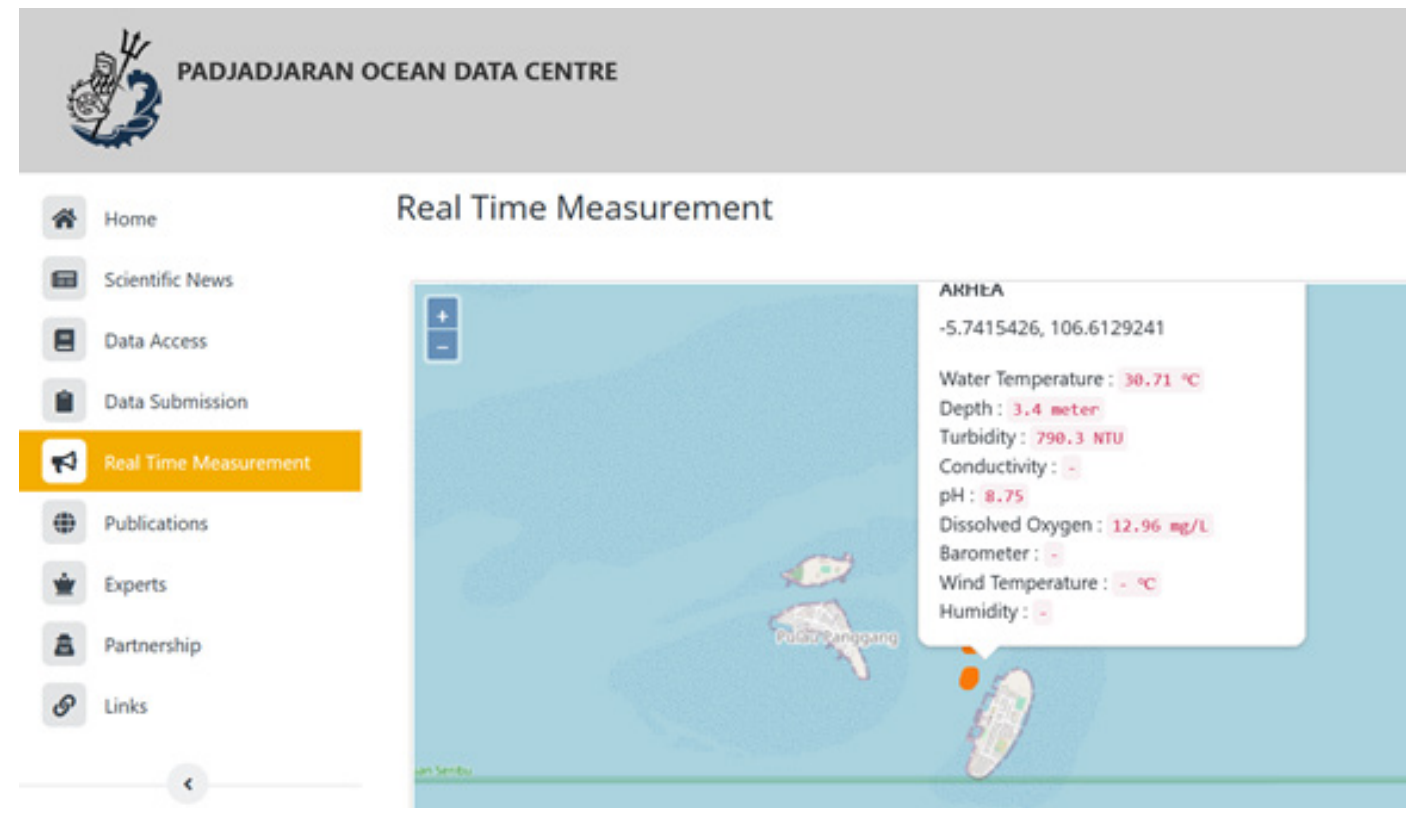

Figure 5. Real-Time Measurement Display on while deploy ARHEA Instrument. Source: PODC Website (https://isea-podc.org/) 
from users. Although more than $55 \%$ of correspondents declare that PODC has good appearances and functions, several evaluations are ahead. Responsive Web Design (RWD) is the first issue that will be fixed immediately, so the users will have a similar experience using different operating systems and platforms. Lastly, the Mobile application version is considerable if the users' demand leads to efficiency and accessibility.

\section{CONCLUSION}

PODC is a central data repository to support open regional oceanography, especially in archipelagic countries. It receives oceanographic data in near realtime and delayed mode from various networks. PODC will support national government and agencies in taking policies regarding ocean management. Data in this portal are archived with a quality control process according to Indonesia national data policy. PODC, through its data management activities, plays a vital role in many ocean studies, such as climate change, illegal fishing, and marine dynamics.

\section{ACKOWLEDGEMENTS}

We would like to say thanks to KOMITMEN Research Group in particular to Arnisa Selvi, Sarah Khairunnisa Anwar, Adli Atamimi, and the Development of the website by BASIC IT Bandung who have been very helpful in offering scientific guidance and outreach throughout the project. This research was funded by AIS (Archipelagic Island State) Grant 2020-2021. Ibnu Faizal is the main contributor to this paper.

\section{REFFERENCE}

Abram, N., Gattuso, J. P., Prakash, A., Cheng, L., Chidichimo, M. P., Crate, S., Enomoto, H., Garschagen, M., Gruber, N., Harper., S., Holland, E., Kudela, R.M., Rice, J., Steffen, K., \& VonSchuckmann, K. (2019). Framing and context of the report. IPCC special report on the ocean and cryosphere in a changing climate, 73-129.

Bensana, E., Lemaître, M., \& Verfaillie, G. (1999). Earth Observation Satellite Management. Constraints, 4(3), 293-299. https://doi. org/10.1023/A:1026488509554

Buck, J.J.H., Bainbridge, S.J., Burger, E.F., Kraberg, A. C., Casari, M., Casey, K.S., Darroch, L., Rio, J. Del, Metfies, K., Delory, E., Fischer, P. F., Gardner, T., Heffernan, R., Jirka, S., Kokkinaki, A., Loebl, M., Buttigieg, P.L., Pearlman, J.S., \& Schewe, I. (2019). Ocean data product integration through innovation-the next level of data interoperability. Frontiers in Marine Science, 6(FEB). https://doi. org/10.3389/fmars.2019.00032
Caballero, I., Steinmetz, F., \& Navarro, G. (2018). Evaluation of the first year of operational Sentinel2A data for retrieval of suspended solids in medium- to high-turbiditywaters. Remote Sensing, 10(7), 982. https://doi.org/10.3390/rs10070982

Carr, M., Lamont, T., \& Krug, M. (2021). Satellite sea surface temperature product comparison for the Southern African marine region. Remote Sensing, 13(7), 1244. https://doi.org/10.3390/rs13071244

Chassignet, E.P., Hurlburt, H.E., Smedstad, O.M., Halliwell, G.R., Hogan, P.J., Wallcraft, A.J., Baraille, R., \& Bleck, R. (2007). The HYCOM (hybrid coordinate ocean model) data assimilative system. Journal of Marine Systems, 65(1-4), 6083.

Converse, T., Park, J., \& Morgan, C. (2004). PHP5 and MySQL bible (Vol. 147). John Wiley \& Sons.

Crockford, D. (2008). JavaScript: The Good Parts: The Good Parts. "O'Reilly Media, Inc."

Dubovik, O., Schuster, G.L., Xu, F., Hu, Y., Bösch, H., Landgraf, J., \& Li, Z. (2021). Grand Challenges in Satellite Remote Sensing. In Frontiers in Remote Sensing. 2, 619818. https://www.frontiersin.org/ article/10.3389/frsen.2021.619818.

Duckett, J. (2011). HTML \& CSS: design and build websites (Vol. 15). Wiley Indianapolis, IN.

Durand, M., Fu, L.-L., Lettenmaier, D.P., Alsdorf, D.E., Rodriguez, E., \& Esteban-Fernandez, D. (2010). The surface water and ocean topography mission: Observing terrestrial surface water and oceanic submesoscale eddies. Proceedings of the IEEE, 98(5), 766-779.

Lubchenco, J., Barner, A.K., Cerny-Chipman, E.B., \& Reimer, J. N. (2015). Sustainability rooted in science. Nature Geoscience, 8(10), 741-745. https://doi.org/10.1038/ngeo2552

Mammen, E. (1993). Bootstrap and wild bootstrap for high dimensional linear models. The Annals of Statistics, 21(1), 255-285 (March, 1993). DOI: 10.1214/aos/1176349025

Miloslavich, P., Bax, N.J., Simmons, S.E., Klein, E., Appeltans, W., Aburto-Oropeza, O., Andersen Garcia, M., Batten, S.D., Benedetti-Cecchi, L., \& Checkley-Jr, D.M. (2018). Essential ocean variables for global sustained observations of biodiversity and ecosystem changes. Global Change Biology, 24(6), 2416-2433. 
Nixon, R. (2014). Learning PHP, MySQL \& JavaScript: With jQuery, CSS \& HTML5. "O'Reilly Media, Inc."

Paskin, N. (2010). Digital object identifier (DOI®) system. Encyclopedia of Library and Information Sciences, 3, 1586-1592.

Pattabhi Rama Rao, E., Udaya Bhaskar, T. V. S. Venkat Shesu, R., Srinivasa Rao, N., Suprit, K., \& Geetha, G. (2018). Marine data services at national oceanographic data centre-India. Data Science Journal, 17, 1-7. https://doi.org/10.5334/ dsj-2018-011

Purba, N.P., Harahap, S.A., Prihadi, D.J., Faizal, I., Mulyani, P.G., Fitriadi, C.A., Pangestu, I.F., Atmoko, P.D., Alfath, A., \& Sitio, J.T. (2017). Pengembangan Instrumen Lagrangian Gps Drifter Combined (Gerned) Untuk Observasi Laut Development of Lagrangian Instrument. Jurnal Kelautan Nasional, 12(3), 109-116.

Setyowati, H.A., Dwinugroho, M.P., Sigit Heru Murti, B.S., Yulianto, A., Ajiwihanto, N.E., Hadinata, J., \& Sanjiwana, A.K. (2018). ESDM One Map Indonesia Indonesia: Opportunities and Challenges to Support One Map Policy based on Applied Web-GIS. IOP Conference Series: Earth and Environmental Science, 165(1). https://doi. org/10.1088/1755-1315/165/1/012021

Shahab, N. (2016). Indonesia: one map policy. Open Government Partnership.

Stonebraker, M. (2010). SQL databases v. NoSQL databases. Communications of the ACM, 53(4), 10-11.

Tatroe, K., \& Maclntyre, P. (2020). Programming PHP: Creating Dynamic Web Pages. O'Reilly Media.

Vignudelli, S., Birol, F., Benveniste, J., Fu, L. L., Picot, N., Raynal, M., \& Roinard, H. (2019). Satellite Altimetry Measurements of Sea Level in the Coastal Zone. Surveys in Geophysics, 40(6), 1319-1349. https://doi.org/10.1007/s10712-01909569-1

von-Schuckmann, K., Holland, E., Haugan, P., \& Thomson, P. (2020). Ocean science, data, and services for the UN2030 Sustainable Development Goals. Marine Policy, 121(February), 104154. https://doi.org/10.1016/j.marpol.2020.104154

Wang, Z.A., Moustahfid, H., Mueller, A.V., Michel, A.P.M., Mowlem, M., Glazer, B.T., Mooney, T.A., Michaels, W., McQuillan, J.S., Robidart,
J.C., Churchill, J., Sourisseau, M., Daniel, A., Schaap, A., Monk, S., Friedman, K., \& Brehmer, P. (2019). Advancing Observation of Ocean Biogeochemistry, Biology, and Ecosystems With Cost-Effective in situ Sensing Technologies. Frontiers in Marine Science, 6(September), 1-22. https://doi.org/10.3389/fmars.2019.00519

Yu, H.R. (2015). Design and implementation of web based on Laravel framework. Conference: 2014 International Conference on Computer Science and Electronic Technology, 6, 302. 
A New Oceanographic Data Portal ...... Data Centre (PODC) (Faisal, I., et al.) 